\title{
The Humanity of Florentino Hornedo in the Humanities
}

\section{Roland Theuas DS. Pada}

\begin{abstract}
This brief essay is a tribute to Florentino Hornedo, a defender of the humanities. I share some biographical notes on the life of Hornedo as well as some of his salient works in Philosophy.
\end{abstract}

Keywords: Hornedo, humanities, ethnology, anthropology

$\mathrm{F}$ lorentino Hornedo was born in the culturally rich and beautiful island of Sabtang, Batanes on October 16, 1938. His hometown in Savidug served as the inspiration for the theoretical, social, and intellectual engagement of his long and productive academic life. He originally intended to pursue his studies in the sciences, for he has loved reading books on biology and animal life, but through the reality of poverty (and the fear of breaking laboratory equipment), he decided to pursue in its place the study of education (mainly because he loved the idea of studying itself). As confused and as random these academic career choices were for him, Hornedo would later on become an intellectual tangled with a caboodle of disciplines in the humanities that would only make sense if we were to look back at his strong love for his cultural roots. It is difficult to say that he had some grand plan to pursue the field of anthropology, philosophy, literature, social science, ethnology, and history so as to bring back the necessary skills and theoretical understanding of the humanities to his beloved Batanes; all I can say from this is that as an intellectual wanderer, he always had a place to call home.

The sudden loss of Hornedo's life was a shock to all those whose lives he touched, especially his students and colleagues. In the early hours of the $9^{\text {th }}$ of December, 2015, he was found alone and clutching his chest in his room at the Saint Dominic College of Batanes. In this solitary departure, his family, friends, colleagues, students, and mentees, are all united in mourning the loss of a paragon of humanity in the humanities. Understanding Hornedo's writings is an intellectual journey that traverses all the walks of life towards the understanding of humanity and its persistence to live life in the most 


\section{THE HUMANITY OF FLORENTINO HORNEDO}

meaningful sense. His initial study of philosophy in his younger years led to the question of values that literature failed to answer. His thesis on the notion of freedom was his timely meditation on developmental and social process of autonomy. ${ }^{1}$ In this work, he emphasized that while freedom is a metaphysical concept, its embodiment is dependent upon the developmental resources that are allotted to the embodiment of freedom that can either enable humanity to pursue its own destiny or overcome barriers that hinder one's pursuit of selfbecoming. The timeliness of this work, however, was in part its own undoing. Due to the political upheavals of the Philippine Martial Law era of the 1970s, Hornedo's book was left unread and copies were kept in a warehouse during the Marcos era only to be picked up and republished by the UST Press in 2000.

Hornedo's strong affinity with the understanding of humanity in the humanities was strongly influenced by the multi-disciplinary approaches of the European intellectual tradition, that had a strong bent on the philosophical tradition of phenomenology, structuralism, and poststructuralism. His essays in his book Pagpapakatao ${ }^{2}$ propose some of the salient points of contemporary theories of philosophy and literature to the meaning and value of understanding humanity in its cultural and existential experience. Hornedo's theoretical understanding of the humanities was not by far limited to the perspective of an ivory-tower theorist sitting smugly in his armchair as the world took its own historical course. His historical and anthropological essays looked back as far as the pre-colonial times of Philippine culture, down to its recent contemporary developments. Works on the aspect of values in Philippine culture and history can be seen in Ideas and Ideals ${ }^{3}$ and Pagmamahalan and Pagumumurahan. ${ }^{4}$

Much of Hornedo's life was dedicated to the development and preservation of Ivatan culture. His multidisciplinary works were instrumental to his cause of understanding and helping his Ivatan roots. The Ivatan in Batanes, was fecund with oral-folk traditions and cultural practices that survived the storm of times much like their naval understanding of the seas and architectural ingenuity has allowed them to weather out the most tempestuous parts of the Philippines. We can understand Hornedo's interest in freedom and autonomous development when we understand his ardent desire for the development of his beloved Batanes to weather out the political and social challenges of contemporary Philippine politics. We can appreciate

\footnotetext{
${ }^{1}$ Cf. Florentino Hornedo, The Power to Be: A Phenomenology of Freedom, (Manila: University of Santo Tomas Publishing House, 2000).

${ }^{2}$ Cf. Florerntino Hornedo, Pagpapakatao and Other Essays in Contemporary Philosophy and Literature of Ideas, (Manila: University of Santo Tomas Publishing House, 2002).

${ }^{3}$ Cf. Florentino Hornedo, Ideas and Ideals: Essays in Filipino Cognitive History, (Manila: University of Santo Tomas Publishing House, 2001).

${ }^{4}$ Cf. Florentino Hornedo, Pagmamahalan at Pagmumurahan, (Quezon City: Office of the Research and Publication, School of Arts and Sciences, Ateneo de Manila University, 1997).
}

(C) 2015 Roland Theuas DS. Pada http://www.kritike.org/journal/issue 17/pada december2015.pdf ISSN 1908-7330

(c) $)$ BY-NC-ND 
his love for literature and ethnology, in the context of his will to preserve the oral traditions and practices, such as the Laji of the Ivatans.

While the academe may mourn for the loss of a productive and creative talent found in Hornedo's work, we are also at a loss when we remember his exceptional life. While he never fathered any children of his own, he was a father (and a mother) 5 to family, relatives, and even complete strangers. A poet, painter, sculptor, and an excellent cook and a baker with an impeccable taste for excellent coffee. He frequently enjoyed going to the cinema, to which he drew most of his examples in the humanities towards understanding human nature. Unknown to a lot of people, he also picked up stray and injured animals on the streets so as to nurse them back to health. He had the nasty habit of drawing unflattering portraits of his teachers in class, to which he often got into trouble in his youth. We will never forget the bushy eyebrows and the distinctively manly moustache backed by an imposing height and a voice that can make man or god shudder in fear and reverence.

In his last few lectures, he shared his thoughts on the symbolism of the owl as a figurehead of philosophy. While owls may have the vision and the ability to see far and wide, they were not productive in the sense that they simply used that capacity to hunt mice. For Hornedo, philosophers should be likened to honeybees. They provide illumination in the dark with their wax, and allow the productive enjoyment of their labour with honey. While I mourn for the loss of a good friend and intellectual father, I am reminded of Theuth and Amon-Ra. The struggle between light and darkness is mitigated by the presence of Theuth, as the shining brilliance of Amon-Ra subsides through the night, it is the persistence of memory that allows Theuth to channel the presence of someone who is absent. May we serve as the moon to the sun that always shined brightly in the life of Florentino Hornedo.

Department of Philosophy and the Graduate School University of Santo Tomas, Philippines

\section{References}

Hornedo, Florentino H., Ideas and Ideals: Essays in Filipino Cognitive History (Manila, University of Santo Tomas Publishing House, 2001). Pagmamahalan at Pagmumurahan (Quezon City: Office of Research and Publication, School of Arts and Sciences, Ateneo de Manila University, 1977).

\footnotetext{
${ }^{5}$ My thanks are extended to Georgina Gabilo for sharing her thoughts and experiences with Florentino Hornedo's life.

(c) 2015 Jove Jim S. Aguas http://www.kritike.org/journal/issue 16/aguas june2015.pdf ISSN 1908-7330 


\section{THE HUMANITY OF FLORENTINO HORNEDO}

Pagpapakatao and Other Essays in Contemporary Philosophy and Literature of Ideas (Manila: University of Santo Tomas Publishing House, 2002).

The Power to Be: A Phenomenology of Freedom (Manila: University of Santo Tomas Publishing House, 2000).

(C) 2015 Roland Theuas DS. Pada

http://www.kritike.org/journal/issue 17/pada december2015.pdf

ISSN 1908-7330

\section{(cc) EY-NC-ND}

